\title{
DEVELOPMENT OF SEED CUBE TEGHNOLOGY FOR SUCGESSFUL AFFORESTATION THROUGH DIRECT SEEDING OF THESPESIA POPULNEA TREES
}

\author{
Jawahar R* \& Umarani $\mathbf{R}$
}

Department of Forest Biology and Tree Improvement, Forest College and Research Institute, Tamil Nadu Agricultural University, Mettupalayam - 641 301, Coimbatore, Tamil Nadu, India,

*jawahar2013007007j@gmail.com

Submitted April 2019; accepted June 2019

\begin{abstract}
Seed balls are gaining popularity as a means to improve tree cover and facilitate ecological restoration. Currently, seed balls are prepared without properly addressing seed dormancy, seed germination percentage and seed vigour. Implementation of latest seed enhancement technologies such as seed coating and seed priming can facilitate germination of tree seed balls. Flat seed cubes have an advantage over spherical shaped seed balls in aiding seed germination and rooting of new germinants. A series of experiments were conducted using Thespesia populnea seeds to standardise seed coating technique, humid priming technique and cube media composition. The results revealed that seeds of $T$. populnea coated with $4 \mathrm{~g} \mathrm{~kg}^{-1}$ Shidocoat (a gibberellic acid-based seed coating formulation developed by Tamil Nadu Agricultural University and marketed by Vriksha Agro Ventures, India) followed by humid priming (24 hours soaking +3 days humid incubation) and embedded in cube media ( $700 \mathrm{~g}$ soil, $130 \mathrm{~g}$ sawdust, $80 \mathrm{~g}$ bone meal, $40 \mathrm{~g}$ vermicompost and $50 \mathrm{~g}$ arbuscular mycorrhizal fungi) recorded an increase of $46.0 \%$ germination, $180.8 \%$ speed of emergence on the $21^{\text {st }}$ day, $7.5 \%$ root length, $23.5 \%$ shoot length, $14.1 \%$ total seedling length, $23.1 \%$ dry matter production and $225.3 \%$ vigour index over the soil cube media. Owing to its significantly superior performance, it is recommended that the improved seed cubes of T. populnea be directly placed on the surface of soil in chosen areas, so that they can germinate when they receive the desired moisture through rainfall or irrigation.
\end{abstract}

Keywords: Seed coating, humid seed priming, seed germination, seedling growth

\section{INTRODUCTION}

Human activities cause degradation of land resources and loss of biodiversity. There is much debate on the restoration of biodiversity following climate change which leads to increased incidence of drought. Restoration activity of tree cover is conducted through conservation techniques, direct seeding or planting of seedlings. Soil seed reserves can restore the full component of forest plant species through natural regeneration but the number of soil seed reserves are now declining by $30-80 \%$ due to damage by rodents and ants (Archer \& Pyke 1991). Direct seeding is also prone to damage by animals. In order to overcome these problems in direct seeding, an ancient method of using seed balls for restoration of flora has recently been brought again to practice by eco-conservationists. Seed ball technique involves enclosing of one or more seeds of plant species in spherical shaped soil-based medium. The seed balls are then dried thoroughly and later used for reforestation by scattering them in distant fallow lands.
Seed balls used in farming practice contain a mixture of variety of seeds, soil, water and clay. Predation by animals and insects are avoidable when using seed balls prepared from clay, fibre and humus (Fukuoka 1978). The author also stated that making seed balls with different mixture of seeds can randomise germination process of seeds progressively and by throwing the seed balls, they may reach unpredictable locations where plants can germinate and establish. Seed balls enhance germination by retaining moisture and nutrient. Thus, seed balls act as a short-term seed bank, from which the seed germinates when favourable conditions are available during monsoon period.

The seed ball concept has been widely used by eco-conservationists to restore green cover in fallow lands in urban and rural areas so as to improve the microclimate and mitigate effects of climate change. However, the seeds used are not subjected to dormancy breaking or seed enhancement treatments to improve 
seed germination potential. Further, the seed balls which are prepared conventionally are not subjected to seed testing to gauge the percentage of the seed germination from seed balls. Soil and farmyard manure are the most commonly used media in preparing seed balls. Necessary components have not been added to decrease bulk density or increase water holding capacity of the media which is very critical for enhancing seed germination. It was also hypothesised that the cube shape of the media may be more effective in facilitating root anchorage of a germinant compared with spherical shape of the seed ball.

Seed coating and seed priming can significantly improve early plant establishment, yield and control of pests (Niranjan et al. 2004). The Tamil Nadu Agricultural University (TNAU), Coimbatore, India has developed a hormonebased seed coating formulation comprising stabiliser, growth hormone (gibberellic acid), pigment and hydrophyllic polymer. The seed coating formulation is currently marketed as Shidocoat by Vriksha Agro Ventures, India. The product has been proven to improve seed germination as well as seedling growth characteristics in many agricultural crops and horticultural crops (Karthi 2017, Leelavathi 2018). There is immense scope to utilise the seed coating technology to improve seed germination and seedling vigour expression in tree seeds.

Seed priming is a controlled hydration process that exposes seeds to low water potentials that restrict germination but permits pre-germinative physiological and biochemical changes. Many priming techniques have been developed for priming seeds such as halopriming, biopriming, osmopriming, solid matric priming, spin priming and humid priming. Humid priming technique is a process of soaking seeds in a loosely tied cloth bag for pre-standardised duration of time, followed by placing the bags in a closed container over a few wooden sticks to drain residual water and provide humid dark condition that promotes the invigoration process (Mohamed 2014). Seeds subjected to $>80 \%$ relative humidity during priming process show improvement in physiological (germination percentage, speed of emergence and vigour index) and biochemical (decrease in seed leachates, higher $\alpha$-amylase activity and increased sugar content parameters) traits (Powell et al. 2000).
Thespesia populnea is a small evergreen tree, 6-10 $\mathrm{m}$ in height, with short crooked stem and broad, dense crown. The tree acts as coastal windbreak as it is resistant to wind and salt spray and grows well on saline and salty conditions. It grows well under long daylight and tolerates drought conditions (Parotta 1994). In the present study, an attempt has been made to improve seed germination and seedling establishment of seed cube technology by incorporating necessary technological innovations. The objectives of the study were to (1) standardise seed enhancement techniques viz. seed coating and seed priming, (2) standardise media composition to include sustainable organic nutrient sources, enhance porosity and water retention capacity besides reducing bulk density, and (3) reshape the seed balls into cuboid structure so as to enhance the chances for better root anchorage of germinants. The seed cube technique developed in the study was evaluated to ascertain its germination performance as well as potential of seedling growth and establishment.

\section{MATERIALS AND METHODS}

A series of experiments were conducted using seeds of T. populnea for developing the seed cube technology, which includes seed enhancement through seed coating and seed priming techniques and standardisation of media with appropriate components to ensure high seed germination and seedling establishment. Thespesia populnea seeds were collected from the Forest College and Research Institute, Mettupalayam.

\section{Experiment 1: Seed coating technique for $T$. populnea seeds}

Thespesia populnea seeds were subjected to seed coating with Shidocoat formulation at 2, 3 and $4 \mathrm{~g} \mathrm{~kg}^{-1}$ seeds. For uniform coating, the weighed quantity of polymer formulation was mixed with $10 \mathrm{~mL}$ of water, mixed well, poured over the seeds placed in a beaker and stirred vigourously with a glass rod to coat the seeds. The coated seeds were dried at room temperature until original moisture content was reached. The coated seeds were subjected to germination test under raised bed conditions maintained inside a shade net by sowing 50 seeds per replication along with control (uncoated) seeds. Four 
replications were maintained. After 21 days, the number of normal seedlings was counted and the percentage of mean germination was determined. Daily observations for germination of seeds were recorded and speed of emergence was calculated using the formula proposed by Maguire (1962). Root length and shoot length were measured $(\mathrm{cm})$. After measuring the total seedling length (root length + shoot length), seedlings were kept in a paper cover $(3 \mathrm{~cm} \times$ $4 \mathrm{~cm}$ ), shade dried for 24 hours and dried in a hot air oven at $80 \pm 2{ }^{\circ} \mathrm{C}$ for 24 hours to record the dry matter production $(\mathrm{mg})$. Vigour index values were calculated using the formula suggested by Abdul-Baki and Anderson (1973) and mean values were expressed as whole numbers.

\section{Experiment II: Humid priming technique for $T$.} populnea seeds

Humid priming technique consists of imbibing seeds in water, incubating them in dark, humid conditions and drying them back to original moisture content. In this experiment, T. populnea seeds were soaked in water for two different durations viz., 12 and 24 hours in separate containers. Later, the water was drained and the imbibed seeds were tied in wet cloth bags and placed in a container over an elevated platform, so as to allow excess water to drain. The containers were closed tightly and placed in dark condition to allow incubation of seeds. Seeds were drawn after 1, 2 and 3 days and then shade dried for 12 hours to attain original moisture content. The humid primed and control seeds were subjected to germination test in raised bed conditions maintained under shade net house and the speed of emergence, seed germination percent, root length, shoot length, total seedling length, dry matter production and vigour index were recorded.
Experiment III: Composition of seed cube media for T. populnea seeds

The media for seed cube was standardised by testing seed germination and seedling growth characteristics of T. populnea. Five components (soil, sawdust, bone meal, vermicompost and VAM (vesicular arbuscular mycorrhiza)) were experimented in different proportions (Table 1).

Media components of the respective treatments were mixed well with water to make a semi-solid paste. A wooden dye was designed for making seed cubes with dimensions of $1.5 \mathrm{~cm}$ (height) $\times 3 \mathrm{~cm}$ (length) $\times 3 \mathrm{~cm}($ breadth $)$. Seed cubes were prepared by applying the semisolid paste of different media composition in the wooden frame. Seeds subjected to best seed coating + humid priming treatment were embedded in the cubes. The wooden frame was tapped gently to extract the wet seed cubes which were dried for 24 hours in a hot air oven maintained at $40{ }^{\circ} \mathrm{C}$.

The dried seed cubes (Figure 1) were subjected to germination test under raised mother bed conditions maintained inside a shade net with 25 seed cubes (two seeds cube ${ }^{-1}$ ) and four replications together, along with control seed cubes which were embedded with raw seeds that were not subjected to either seed coating or humid priming. The seed cubes were placed on the surface of the bed and watered daily. Observations were made on speed of emergence, seed germination percentage, root length, shoot length, total seedling length, dry matter production and vigour index.

Data were analysed using analysis of variance (ANOVA) as factorial combination of treatments. Means were separated on the basis of least significant difference only if $\mathrm{F}$ test of ANOVA for treatments was significant at 0.05 or 0.01

Table 1 Composition of seed cube media

\begin{tabular}{cccccc}
\hline Treatment & \multicolumn{5}{c}{ Component } \\
\cline { 2 - 5 } & $\begin{array}{c}\text { Soil } \\
(\mathrm{g})\end{array}$ & $\begin{array}{c}\text { Sawdust } \\
(\mathrm{g})\end{array}$ & $\begin{array}{c}\text { Bone meal } \\
(\mathrm{g})\end{array}$ & Vermicompost $(\mathrm{g})$ & $\begin{array}{c}\text { VAM } \\
(\mathrm{g})\end{array}$ \\
\hline $\mathrm{T} 1$ & 1000 & 0 & 0 & 0 & 0 \\
$\mathrm{~T} 2$ & 850 & 150 & 0 & 0 & 0 \\
$\mathrm{~T} 3$ & 700 & 130 & 170 & 0 & 0 \\
$\mathrm{~T} 4$ & 700 & 130 & 80 & 40 & 50 \\
\hline
\end{tabular}

$\mathrm{VAM}=$ vesicular arbuscular mycorrhiza 


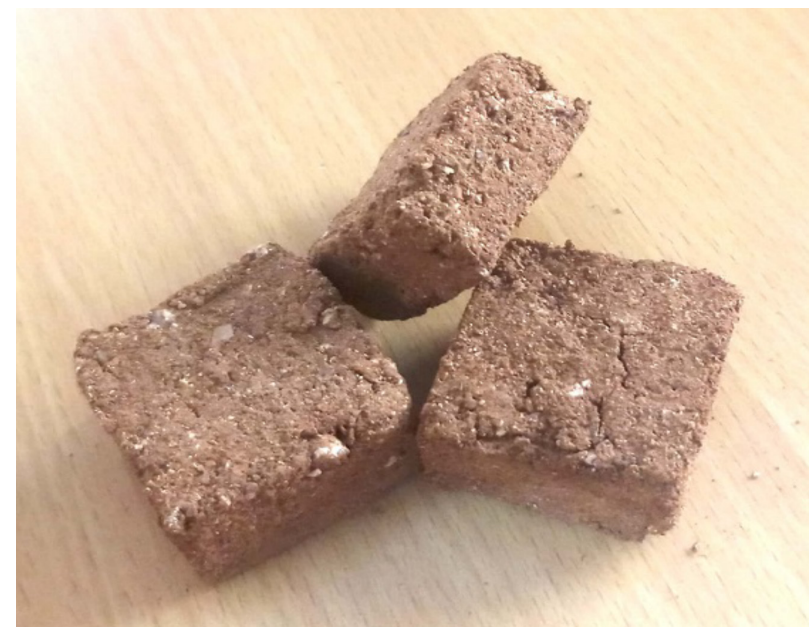

Figure 1 Thespesia populnea seed cubes

probability level. Values in percent data were arcsine transformed before analysis.

\section{RESULTS AND DISCUSSION}

In the first experiment, influence of Shidocoat formulation on $T$. populnea was studied at three concentrations $\left(2,3\right.$ and $\left.4 \mathrm{~g} \mathrm{~kg}^{-1}\right)$. Of the three concentrations, $4 \mathrm{~g} \mathrm{~kg}^{-1}$ demonstrated the highest potential to enhance seed germination and seedling vigour of T. populnea by registering the highest germination percentage $(80 \%)$, speed of germination (4.28), root length $(6.99 \mathrm{~cm})$, shoot length $(5.39 \mathrm{~cm})$, total seedling length $(12.38 \mathrm{~cm})$, dry matter production (1212 mg seedling-10 ${ }^{-10}$ and vigour index (96960) (Table 2). The values were $24,47.6,8.9,0.9$, $5.3,11.8$ and $59.7 \%$ higher than the control seed respectively. The results obtained were in concordance with the findings made on the effect of Shidocoat on seed germination and seedling vigour of agricultural and horticultural crops. Improvement obtained when using Shidocoat may be attributed to the hydrophylic nature of the polymer used in the formulation and the growth hormone (gibberellic acid) (Karthi 2017). The effect of gibberellic acid on seed germination has been reported in various crops.

The second experiment was conducted to standardise the humid priming for improving the vigour potential of T. populnea seeds. The experiment revealed that seeds soaked for 24 hours and incubated for 3 days recorded the highest seed germination (54\%), whereas control seeds recorded only $14 \%$ germination (Table 3 ).
The speed of germination was also highest in the former (2.77) compared with control seeds (0.61) revealing that humid priming technique had significantly improved the seed vigour potential of T. populnea seeds. Root length, shoot length, dry matter production and vigour index of seeds after humid priming (24 hours soaking +3 days humid incubation) were 40.4, 19.6, 37.9 and $431.8 \%$ higher than the control seeds respectively (Table 3 ).

In the third experiment, T. populnea seeds were subjected to seed coating with Shidocoat at $4 \mathrm{~g} \mathrm{~kg}^{-1}$ before soaking for 24 hours and 3 days incubation. These seeds were used to standardise the optimum cube media. Between the four media compositions, T4 (mixture of clay, saw dust, bone meal, vermicompost and VAM) recorded the highest germination percentage $(74 \%)$ compared with T1 (28\%), T2 (36\%), T3 $(60 \%)$ and untreated, raw seeds $(36 \%)$. The speed of germination in T4 was also highest (234\% over control) (Figure 2). Root length, shoot length, dry matter production and vigour index of enhanced seeds embedded in seed cubes made up of T4 media had the highest values compared with control, i.e. 15.5, 14.5, 32.8 and $172.5 \%$ respectively (Table 4 , Figure 3 ).

The composition of media influenced germination and vigour of T. populnea seeds. T1 media was composed of only soil which may hinder seed germination due to high bulk density and mechanical restraint (Kooistra \& Tovey 1994). Treatment T2 comprised clay and saw dust which increased porosity and water holding capacity and resulted in higher germination $(36 \%)$ than T1 media (Table 4). T3 treatment recorded 46 and $38 \%$ higher germination over $\mathrm{T} 1$ and $\mathrm{T} 2$ media respectively. Seeds in T4 media had the best growth potential compared with control or the rest of the media as it recorded an increase of $46.0 \%$ germination, $180.8 \%$ speed of emergence on the $21^{\text {st }}$ day, $7.5 \%$ root length, $23.5 \%$ shoot length, $14.1 \%$ total seedling length, $23.1 \%$ dry matter production and $225.3 \%$ vigour index over the soil cube media (T1). Vermicompost and VAM in T4 medium could have enhanced seedling growth and vigour (Ravikumar et al. 1997, Roy et al. 2010).

From the experiment, it was concluded that in order to achieve high success in reforestation efforts with $T$. populnea, the seeds should be subjected to seed coating using Shidocoat at $4 \mathrm{~g} \mathrm{~kg}^{-1}$ and then to humid priming (24 hours 
Table 2 Effects of Shidocoat on seed germination and seedling vigour of Thespesia populnea seeds

\begin{tabular}{lccccccc}
\hline Treatment & $\begin{array}{c}\text { Germination } \\
(\%)\end{array}$ & $\begin{array}{c}\text { Speed of } \\
\text { emergence }\end{array}$ & $\begin{array}{c}\text { Root length } \\
(\mathrm{cm})\end{array}$ & $\begin{array}{c}\text { Shoot length } \\
(\mathrm{cm})\end{array}$ & $\begin{array}{c}\text { Total seedling } \\
\text { length } \\
(\mathrm{cm})\end{array}$ & $\begin{array}{c}\text { Dry matter } \\
\text { production } \\
\left(\mathrm{mg} \mathrm{seedlings}^{-10}\right)\end{array}$ & $\begin{array}{c}\text { Vigour } \\
\text { index }\end{array}$ \\
\hline Shidocoat & & & & & & & \\
$\quad 2 \mathrm{~g} \mathrm{~kg}^{-1}$ & $62(51.94)$ & 2.93 & 5.77 & 5.25 & 11.02 & 1105.16 & 68,520 \\
$3 \mathrm{~g} \mathrm{~kg}^{-1}$ & $70(56.79)$ & 3.93 & 6.77 & 5.37 & 12.14 & 1158.29 & 81,080 \\
$4 \mathrm{~g} \mathrm{~kg}^{-1}$ & $80(63.43)$ & 4.28 & 6.99 & 5.39 & 12.38 & 1212.00 & 96,960 \\
Control & $56(48.44)$ & 2.90 & 6.42 & 5.34 & 11.76 & 1083.93 & 60,700 \\
Mean & $67(54.93)$ & 3.51 & 6.49 & 5.34 & 11.82 & 1139.84 & 76815 \\
SED & 1.48 & 0.08 & 0.14 & 0.11 & 0.25 & 24.23 & 173.69 \\
$\mathrm{CD}(\mathrm{p}=0.05)$ & 3.42 & 0.18 & 0.32 & 0.26 & 0.58 & 55.87 & 400.53 \\
\hline
\end{tabular}

$\mathrm{SED}=$ Standard error of a difference, $\mathrm{CD}=$ confidence distribution; figures in the parentheses are arc sine values

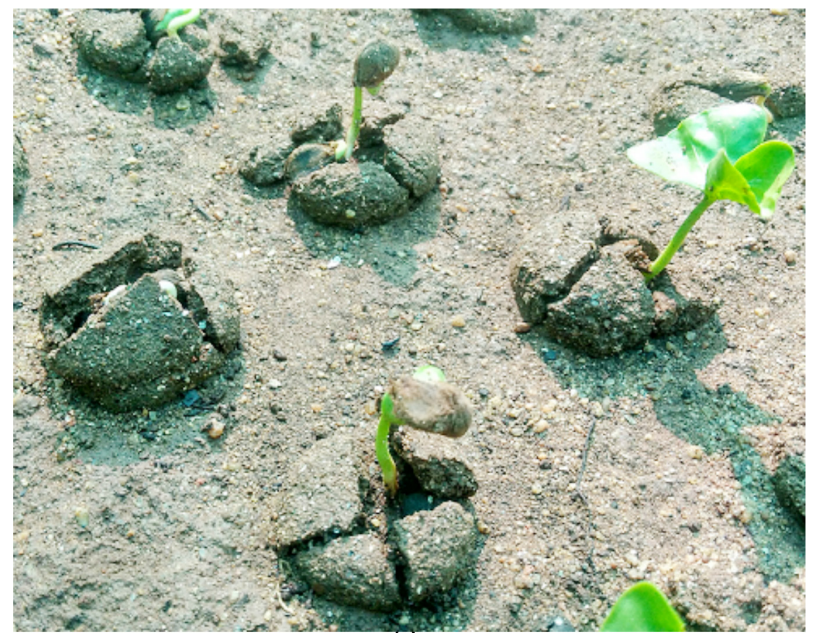

Figure 2 Seed cube composition T4 (mixture of clay, saw dust, bone meal, vermicompost and VAM) enables breaking up of seed cubes to allow emergence of seedlings of T. populnea

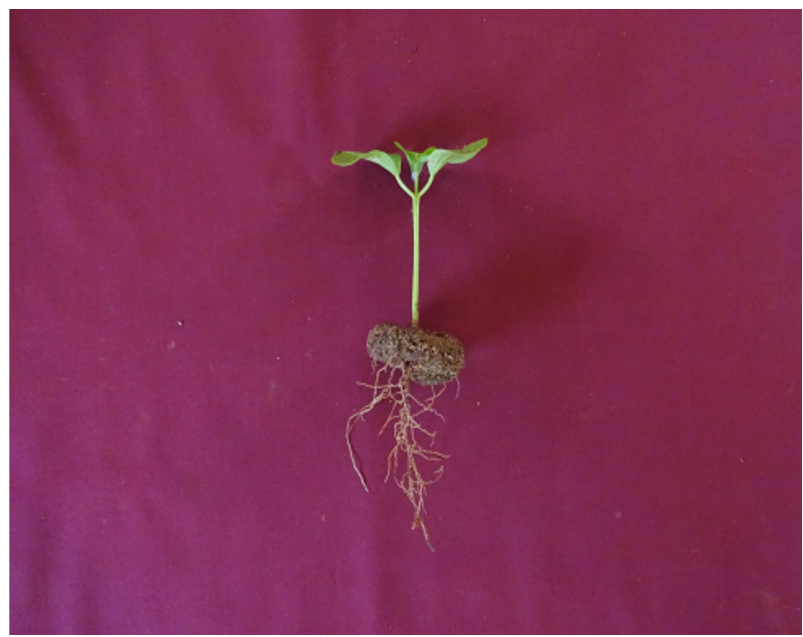

Figure 3 Tap root and secondary root growth enhanced by $\mathrm{T} 4$ seed cube in T. populnea

Table 3 Effects of humid priming on seed germination and seedling vigour of T. populnea seeds

\begin{tabular}{|c|c|c|c|c|c|c|c|c|}
\hline \multicolumn{2}{|c|}{ Humid priming } & \multirow{2}{*}{$\begin{array}{c}\text { Germination } \\
(\%)\end{array}$} & \multirow{2}{*}{$\begin{array}{l}\text { Speed of } \\
\text { emergence }\end{array}$} & \multirow{2}{*}{$\begin{array}{l}\text { Root } \\
\text { length } \\
(\mathrm{cm})\end{array}$} & \multirow{2}{*}{$\begin{array}{l}\text { Shoot } \\
\text { length } \\
(\mathrm{cm})\end{array}$} & \multirow{2}{*}{$\begin{array}{l}\text { Total seedling } \\
\text { length } \\
(\mathrm{cm})\end{array}$} & \multirow{2}{*}{$\begin{array}{c}\text { Dry matter } \\
\text { production } \\
\left(\mathrm{mg} \mathrm{seedlings}^{-10}\right)\end{array}$} & \multirow{2}{*}{$\begin{array}{l}\text { Vigour } \\
\text { index }\end{array}$} \\
\hline $\begin{array}{c}\text { Soaking } \\
\text { (hours) }\end{array}$ & $\begin{array}{c}\text { Humid } \\
\text { incubation } \\
\text { (days) }\end{array}$ & & & & & & & \\
\hline \multirow[t]{3}{*}{12} & 1 & $32(34.45)$ & 1.32 & 6.22 & 4.60 & 10.82 & 1113.13 & 35,620 \\
\hline & 2 & 38 (38.06) & 1.28 & 6.23 & 4.62 & 10.85 & 1120.00 & 42,560 \\
\hline & 3 & $42(40.40)$ & 2.29 & 6.36 & 4.75 & 11.12 & 1155.24 & 48,520 \\
\hline \multirow[t]{3}{*}{24} & 1 & $40(39.23)$ & 1.80 & 5.85 & 4.6 & 10.45 & 1020.00 & 40800 \\
\hline & 2 & $44(41.55)$ & 2.66 & 5.96 & 4.70 & 10.65 & 1222.73 & 53,800 \\
\hline & 3 & $54(47.29)$ & 2.77 & 6.64 & 5.01 & 11.65 & 1258.52 & 67,960 \\
\hline Control & & $14(21.97)$ & 0.61 & 4.73 & 4.19 & 8.91 & 912.86 & 12,780 \\
\hline Mean & & 37 (21.97) & 1.82 & 6.00 & 4.64 & 10.63 & 1114.64 & 43148 \\
\hline SED & & 1.00 & 0.05 & 0.15 & 0.12 & 0.27 & 28.48 & 1161.34 \\
\hline $\mathrm{CD}(\mathrm{p}=0$. & & 2.19 & 0.11 & 0.33 & 0.25 & 0.59 & 62.05 & 2530.36 \\
\hline
\end{tabular}

Figures in the parentheses are arc sine values 
Table 4 Effects of seed cube media on T. populnea seeds enhanced by seed coating and humid priming

\begin{tabular}{lccccccc}
\hline Treatment & $\begin{array}{c}\text { Germination } \\
(\%)\end{array}$ & $\begin{array}{c}\text { Speed of } \\
\text { emergence }\end{array}$ & $\begin{array}{c}\text { Root length } \\
(\mathrm{cm})\end{array}$ & $\begin{array}{c}\text { Shoot length } \\
(\mathrm{cm})\end{array}$ & $\begin{array}{c}\text { Total seedling } \\
\text { length }(\mathrm{cm})\end{array}$ & $\begin{array}{c}\text { Dry matter } \\
\text { production } \\
\left.\text { (mg seedlings }^{-10}\right)\end{array}$ & $\begin{array}{c}\text { Vigour } \\
\text { index }\end{array}$ \\
\hline T1 & $28(31.95)$ & 1.87 & 6.44 & 4.60 & 11.04 & 1414.29 & 39,600 \\
T2 & $36(36.87)$ & 3.05 & 6.64 & 5.48 & 12.12 & 1418.89 & 51,080 \\
T3 & $60(50.77)$ & 4.02 & 6.70 & 5.55 & 12.24 & 1540.00 & 92,400 \\
T4 & $74(59.34)$ & 5.25 & 6.92 & 5.68 & 12.60 & 1740.54 & 128,800 \\
Control & $36(36.87)$ & 1.57 & 5.99 & 4.96 & 10.96 & 1310.56 & 47180 \\
Mean & $46(43.17)$ & 3.15 & 6.54 & 5.25 & 11.79 & 1484.85 & 71,812 \\
SED & 1.28 & 0.09 & 0.15 & 0.12 & 0.28 & 35.48 & 2075.43 \\
CD $(\mathrm{p}=0.05)$ & 2.85 & 0.20 & 0.34 & 0.27 & 0.62 & 79.04 & 4624.38 \\
\hline
\end{tabular}

soaking + 3 days humid incubation). The enhanced seeds should be embedded in seed cubes made up of soil, saw dust, bone meal, vermicompost and VAM (T4 medium), and dried well. The dried seed cubes can be used for surface sowing in fallow areas in urban, rural and forest areas to attain high percentage of tree establishment on receipt of moisture through rainfall or irrigation. It is concluded that instead of using seed balls, seed cubes can be promoted for obtaining higher germination and vigour, which will be more effective for tree cover restoration in degraded areas.

\section{REFERENCES}

Abdul-BAKi AA \& Anderson JD. 1973. Vigor determination in soybean seed by multiple criteria 1 . Crop Science 13: 630-633.

Archer S \& Pyke DA. 1991. Plant-animal interactions affecting plant establishment and persistence on re-vegetated rangeland. Journal of Range Management 44: 558-565. doi:10.2307/4003035.

Fukuoka M. 1978. The One-Straw Revolution. Rodale Press Inc., Emmaus

Karthi P. 2017. Development of hormone based seed coating formulation to improve seed germination and seedling vigour of crop seeds. MSc (Ag) thesis, Tamil Nadu Agricultural University, Coimbatore.

Koolstra MJ \& Tovey NK. 1994. Effects of compaction on soil microstructure. Pp 91-112 in Soane BD \& Van Ouwerberk C (eds) Soil Compaction in Crop Production. Elsevier, New York.

Leelavathi. 2018. Evaluation of seed enhancement technologies for improvement in crop growth and productivity. MSc thesis, Tamil Nadu Agricultural University, Coimbatore.

Maguire JD. 1962. Speed of germination-aid selection and evaluation for seedling emergence and vigor. Crop Science 2: 176-177. doi:10.2135/ cropsci1962.0011183x0002

Moнамed M. 2014. Assessment of factors influencing seed propagation of Melia dubia Cav. MSc thesis, Tamil Nadu Agricultural University, Coimbatore.

Niranjan Raj N, Shetty NP \& Shetty HS. 2004. Seed biopriming with pseudomonas fluorescens isolates enhances growth of pearl millet plants and induces resistance against downy mildew. International Journal of Pest Management 50: 41-48. https: / / doi.org/10.10 80/09670870310001626365.

Parotta JA. 1994. Thespesia populnea (L.) Soland. ex Correa. In Silvics of Native and Exotic Trees of Puerto Rico and Caribbean Islands. SO-ITF-SM-76. USDA Forest Service, International Institute of Tropical Forestry, Puerto Rico.

Powell AA, Yule LJ, Jing HC, Groot SP, Bino RJ \& Pritchard HW. 2000. The influence of aerated hydration seed treatment on seed longevity as assessed by the viability equations. Journal of Experimental Botany 51: 2031-2043. https://doi.org/10.1093/ jexbot/51.353.2031.

Ravikumar R, Ananthakrishnan G, Appasamy T \& Ganapathi A. 1997. Effect of endomycorrhizae (VAM) on bamboo seedling growth and biomass productivity. Forest Ecology and Management 98: 205-208. https://doi. org/10.1016/S0378-1127(97)00107-2.

Roy S, Arunachalam K, Dutta BK \& Arunachalam A. 2010. Effect of organic amendments of soil on growth and productivity of three common crops viz. Zea mays, Phaseolus vulgaris and Abelmoschus esculentus. Applied Soil Ecology 45: 76-84. https://doi.org/10.1016/j. apsoil.2010.02.004. 